\title{
FROM IMPLICIT NORMS TO EXPLICIT SKILLS \\ - FOCUSING ON DANISH ACADEMIC VOCABULARY
}

\author{
ANNE SOFIE JAKOBSEN
}

\section{ABSTRACT}

Research shows that L1 as well as L2 and L3 students in Danish tertiary education struggle with acquiring the necessary academic language skills for studying in Danish. Research also shows a tendency for educators in the Danish setting to treat academic language norms as implicit norms, making it much harder for students to grasp the language-related demands of academia. This article argues that in order to make the demands and norms of academic language explicit to the students, irrespective of linguistic background, we need more research-based knowledge about Danish academic language. Furthermore, focussing on one particular aspect of academic language, namely academic vocabulary, can be a step towards more explicit approaches to academic language norms. Academic vocabulary is here defined as a non-technical, general purpose vocabulary with distinct academic functions used across a range of academic disciplines. To come nearer an understanding of how we can make the academic language norms more tangible and accessible to both students and staff, the article begins with a review of existing research on Danish academic language and academic vocabulary with a particular focus on Danish SLA research. This is followed by an analysis of Danish guidance literature on academic writing for students. The article concludes with suggestions for further research in relation to teaching Danish academic vocabulary.

\section{[1] INTRODUCTION}

This article argues for a more explicit focus on academic vocabulary in relation to teaching academic language skills to L1 as well as L2, and L3 students in the Danish educational context, especially within Danish higher education. It also stresses the need for more research on Danish academic language with a focus on academic vocabulary. An explicit focus on academic vocabulary is motivated by the vast array of research, especially in English, which shows that this type of vocabulary is an essential component of academic language skills (e.g. Coxhead 2000; Biber 2006; Paquot 2010; Nation 2013; Gardner \& Davies 2014). 
Specific fields of study are usually identified by the use of specialised technical vocabularies and certain genre norms. Academics, however, do not only need to master the discipline-specific vocabulary within their own field of study, but must also be able to understand and use an academic vocabulary which is nontechnical and general purpose in nature and used across a range of academic disciplines. Academic words (e.g. anticipate, compatible and phenomenon), and phrases (e.g. as a function of, in the case of, to some extent) can be considered the glue of academic language, serving a range of functions in relation to presenting information, building argumentation, scaffolding, signposting, quantifying and stance-setting the content proper, i.e. the technical information to be conveyed in the academic text (Biber 2006; Simpson-Vlach \& Ellis 2010; Ranney 2012). The hallmark of academic discourse, in both written and oral form, is precision and nuance in expression, often at word choice level, e.g. created through the appropriate use of academic vocabulary. Thus, in order to convey information and create argumentation in a clear and convincing way, academic vocabulary must be easily accessible to the academic writer, enabling them to focus their attentional resources on the central content and the academic argument itself.

In the Danish educational context, academic language is often viewed as a stilted and somewhat superfluous language form which only serves to complicate complex matters further (Henriksen 2014). The sentiment seems to be: why do you need to complicate your language to say what you think? Academic language is regarded by some as a form of language that creates a distance between the researcher and the surrounding world. These views on academic language are, for example, expressed in a commentary in the Danish newspaper Politiken by a student of rhetoric who argues that academic language, which he describes as hyper-complex and stilted, hinders the dissemination of research to society (Scheuer 2016). Comments such as Sheuer's on academic language miss the point to a large degree. Academic language should not be a stilted and complicated language form, but rather, as Snow and Uccelli (2009, 123) point out, an adequate response to a complex communicative challenge. In line with this point, Leth-Andersen and Skov (2013), in a comment to a PhD student questioning the abstruseness of academic language, argue that academic language has a clear function as a professional tool for communicating research and as such should be objective, unambiguous and precise. Arguably, negative attitudes to academic language are coloured by misconceptions about what academic language in fact is, but research grounded in the Danish context shows that the criteria and norms of academic language are opaque, even invisible, to many students (Knudsen 2009; Kristiansen 2010; Skov 2013; Blom et al. 
2016; Ankersborg \& Pogner 2016). This is also reflected in the many anecdotes from both students and staff in higher education about how the students struggle with learning the linguistic codes of academia, and about how no one teaches the students these codes (Skov 2006a). Such anecdotes together with the attitudes expressed above seem to spring from an educational reality which has largely failed to explain and teach the core linguistic aspects of academic language use, including the purpose of adopting specific language forms and a specific style. This view of academic language as an unnecessarily complicated and distance-creating form of language use is most likely caused by a lack of explicit focus on academic language skills throughout the educational system. If we turn to official guidelines regulating Danish education, such an implicit treatment of academic language skills stands in stark contrast to clear curricular demands concerning development of language skills and genre awareness both in primary and secondary school as well as in tertiary education (see the Ministerial Order on University Examination, chapter 4, § 26 and the Ministerial Order on Upper-Secondary School, appendix 4).

This article attempts to shed light on how to convert the implicit linguistic norms of academia to explicit skills by focussing on the vocabulary aspect of academic language It does so by addressing the following three questions:

(i) What does the existing research literature tell us about the role and nature of academic language and especially academic vocabulary?

(ii) What do we know about the needs of the L1, L2 and L3 students in the Danish context?

(iii) How are the concepts of academic language and academic vocabulary defined and conveyed in the Danish guidance literature on academic writing in higher education?

\section{[2] ACADEMIC LANGUAgE AS A SPECIAL AND DEMANDING CODE}

As pointed out by Nagy and Townsend $(2012,92)$, "academic language is the specialized language, both written and oral, of academic settings that facilitates communication and thinking about disciplinary content." In other words, academic language is an important tool for gaining, sharing and developing both practical and theoretical knowledge within any field of study in primary, secondary as well as tertiary education. Academic language can be an obstacle, however, in relation to understanding and producing knowledge in specialized areas of study, e.g. science subjects (Snow \& Uccelli 2009; Snow 2010), and 
therefore demands special attention in all curricula to ensure optimal subject area learning. The present article concentrates on academic language within tertiary education in Denmark, but the challenges of academic language in tertiary education are closely linked to issues concerning language use within the subjects in the Danish primary and secondary school in two ways. Firstly, the acquisition of academic language skills, or what Cummins (1980) terms Cognitive Academic Language Proficiency (CALP), constitutes a challenge similar to that experienced in tertiary education, namely that for the learner of academic language, irrespective of age, it is a matter of not only learning a new form of language, but also learning to do new things with this new language (Nagy \& Townsend 2012, 93). Students at all levels of education need to learn how to think and function academically within specialized domains while at the same time acquiring the code to operate with and convey the acquired knowledge. Secondly, there is a tendency to blame the linguistic shortcomings of tertiary education students on secondary school outcomes, i.e. implying that especially upper-secondary school education does not adequately prepare students in terms of e.g. writing correctly and in an appropriate style.

While only a few studies have looked at the learning needs of L1 students in relation to Danish academic language skills, recent years have seen a growing focus on students with Danish as their second language and their linguistic challenges in academia. In this context, Lund and Bertelsen (2008a, 49-50; 2008b) define academic language as a distinct and cognitively demanding form of language use, and they argue that it can be difficult for L2 students to understand since their comprehension of it depends to a high degree on their understanding of the L2 in general. Lund and Bertelsen's (2008a; 2008b) study showed that L2 students who passed the Higher Education Examination, an entry exam for tertiary education L2 students with a non-qualifying entrance exam, were not adequately prepared for studying in Danish. Based on these findings, Lund \& Bertelsen argue that L2 students' struggle with understanding academic language is connected to the fact that academic language is often used in contextreduced settings which offer only few or no non-linguistic remedies for the L2 students' comprehension of the academic issue at hand. In a large-scale investigation of Icelandic students studying in Denmark and their experiences with and needs for Danish language skills (Hauksdóttir 2012), it was reported that the students experience shortcomings in their productive skills in relation to academic language use. Specifically, it is knowing and being able to navigate the various genre demands of academic language use that pose a challenge (Hauksdóttir 2012, 235-37). Moreover, vocabulary is reported as a recurring problem for the Icelandic students in their mastering of Danish academic lan- 
guage skills (ibid., 237). K.Å. Laursen (2013) found in her study on the disciplinary and linguistic difficulties encountered by university students with Danish as a second language that these difficulties exist in a "grey zone between language and discipline." (K. Å. Laursen 2013, 78, my translation). Moreover, it was found that academic language functions such as Analysis, Definition, Discussion, etc. (Bailey et al., 2007 in K.Å. Laursen 2013, 21) used by teachers in e.g. exam questions were rarely explained to the students. K.Å. Laursen argues that by rendering visible the linguistic meaning of the academic language functions, the discipline teachers can help the students in learning not only the academic language but also the disciplinary content (K. Å. Laursen 2013, 78-80). Odgaard's (2014) study is similar to K.Å. Laursen's (2013) in its focus on university students with Danish as a second language and their needs for and attitudes to academic language. Through a survey and interviews with staff and students at a university department, the study confirms the implicitness of academic language norms from both staff and students' points of view, and Odgaard (2014, 93-95) argues for ways of making these norms explicit. Another investigation of the linguistic and disciplinary challenges of university students with Danish as their second language showed that 67 percent of L2 students contacting the university's student support unit reported difficulties with their written proficiency, while 13 percent reported that vocabulary was a specific challenge for them (Møller 2014, 11). Likewise, in an article on Nordic students studying in Denmark, Holmen (2016) argues for a university pedagogical approach which includes more focus on the linguistic challenges experienced by these students. Although the studies reviewed above focus on different groups of students, they all point to various linguistic aspects of academic language, including vocabulary, as significant challenges for L2 and L3 students. Moreover, the Danish research literature on academic writing indicates that Danish L1 students also struggle with understanding and especially producing academic language because of its implicitness (Kristiansen 2010; Skov 2006b; Skov 2013; Blom et al. 2016; Ankersborg \& Pogner 2016). This is further emphasised by Knudsen (2009, 50) who, in her discussion of the invisibility of academic language, points out that mastering the academic sense of general words is a challenge for most students, and that there is a consequent need for making the different components of academic language, including vocabulary, more visible to students.

\section{[2.1] Academic word lists as pedagogical guidance tools}

As shown above, vocabulary is a component of academic language which creates problems for students. Focus on academic vocabulary has long been an important element in preparing students for English-medium education, and, 
thus, the question of which words can be considered academic is central to much research on English academic language. This has led to the development of a number of word lists containing academic lexical items (e.g. Coxhead 2000; Paquot 2010; Gardner \& Davies 2014; Simpson-Vlach \& Ellis 2010). These studies all use corpus-linguistic methods for selecting academic words. While there is debate as to where to set the cut-off in regards to high-frequency vocabulary (see below), academic words are usually defined as the lexical items that appear with a certain distribution and dispersion across a range of academic disciplines. Coxhead (2000) was the first to develop a word list using frequency and range as criteria for selection words in a corpus. Coxhead's Academic Word List of 570 word families is still widely used in the teaching of English for Academic Purposes. As technology has allowed for larger corpora and more sophisticated selection methods, new lists have been developed (e.g. Gardner \& Davies 2014, and Paquot 2010). Moreover, lists of multiword units have been developed as it has become increasingly clear that academic language makes heavy use of collocations and lexical phrases (e.g. Simpson-Vlach \& Ellis 2010).

Most research on academic vocabulary has been carried out in English, but a corpus-linguistic word list approach has been adopted by researchers interested in academic vocabulary in the Scandinavian languages. A Norwegian academic vocabulary list of 750 single words was developed on the basis of a 100 million word corpus comprising texts from a range of academic disciplines with the specific purpose of helping students in their academic writing (Hagen, Johannessen, \& Saidi 2016). A similar aim was suggested by the Swedish researchers behind a Swedish academic word list based on two corpora of academic written texts from different disciplines (Carlund, Jansson, Johansson Kokkinakis, Prentice, \& Ribeck 2012; Jansson, Johansson Kokkinakis, Ribeck, \& Sköldberg 2012; Sköldberg \& Johansson Kokkinakis 2012).

In addition, attempts to identify academic words in languages such as Portugese (Baptista, Costa, Guerra, Zampieri, Cabral, \& Mamede 2010) and French have been made. Cobb and Horst (2004) investigated whether Coxhead's method of excluding the first 2,000 words when developing the Academic Word List is a good idea for developing a French academic word list. They concluded after having examined the lexical coverage of the 3,000 most frequent words of French in academic and non-academic texts ( 81.27 percent and 83.88 percent respectively, English: 70.42 percent and 81.26 percent respectively) that excluding the first 2,000 words is not desirable for French due to the high coverage that the 2,000 most frequent words of French offered in academic written language use. Cobb and Horst (2004) argue that French high-frequency words have both general and academic meanings. Their findings highlight the importance 
of taking into account the role of high-frequency vocabulary in academic language use when identifying an academic vocabulary, which is something more recent academic vocabulary list studies have done (e.g. Paquot 2010; Gardner \& Davies 2014; Dang 2017).

\section{[2.2] Research on Danish academic vocabulary}

Not much specific research on Danish academic vocabulary has been carried out, and no academic word lists have been developed so far. The development of word lists, such as the ones described above, is dependent on the existence of corpora to be used for the selection of words, and until recently, no such corpora had been developed for Danish. Jakobsen (2016) describes the establishment of a Danish corpus, the AcaDan corpus, consisting of professional academic writing from a range of academic disciplines, which is to be used for identifying Danish academic vocabulary and for subsequent word list development.

The vocabulary aspect of academic language has received some attention within Danish SLA, however. Inspired by Norwegian research in the early 1980s on the vocabulary of school textbooks in physics, geography and history, which showed that a large portion of non-technical words could, in fact, be considered technical due to their frequency in the school books (Golden 1984, in Gimbel, 1994; 1995), Gimbel (1994; 1995) introduced the concept of pre-technical words (in Danish 'førfaglige'), a concept which has gained much attention in Danish SLA research. Pre-technical words are words which occur in disciplinespecific contexts but which are rarely explained by the subject teacher because they are assumed to be known by most language users. Gimbel $(1994 ; 1995)$ examined 32 school children's understanding of pre-technical words. Two groups of school children, $16 \mathrm{~L} 2$ and $16 \mathrm{~L} 1$ students, were asked to give definitions for 50 words that were neither general nor clear technical words, but which were found in textbooks from the subjects of geography, biology and history. Finding that the children with Danish as their L2 had some difficulties explaining these words in comparison with L1 children, Gimbel called for more focus on vocabulary in the teaching of Danish as a second language (Gimbel 1995, 31-33). Lund and Bertelsen (2008a; 2008b), in their studies on students with Danish as L2 in tertiary education, employ the concept of grey-zone words (in Danish 'gråzone'), which seems to include both Gimbel's pre-technical words as well as academic vocabulary. Grey-zone words are defined as distinct from general vocabulary and used in a range of subjects, but with different senses depending on the subject they are used within (Lund 2016, 85). Teachers will often use these words, which they believe are well known to the students, to explain terminology (cf. Snow 2010, 452). While language and words defined as grey- 
zone by Lund and Bertelsen (2008a; 2008b) and Lund (2016) arguably constitute a challenge for learners of Danish, the merging of what Nation (2013) defines as two different types of vocabulary (technical vs academic) into a collective term, grey-zone words, risks making it difficult to operationalise such a term pedagogically. Furthermore, there is a tendency in Danish SLA research to liken pretechnical words to academic vocabulary (see H.P. Laursen 2006, 39; Weber 2009, 52-53; K. A. Laursen 2013, 21). Such a merger entirely misses the point that pretechnical and academic words are in fact two different types of vocabulary. Nation and Kyongho $(1995,37)$ argue that even though vocabulary types cannot be clearly separated dividing words into different categories of vocabulary is important for teaching. The Danish research accounted for here highlights the challenges of especially pre-technical words and the implications of not teaching them, and it points to the fact that more empirically based research on the vocabulary types of Danish academic language, including a specific focus on academic vocabulary, is needed.

The literature on vocabulary in Danish academic language use reviewed so far not only confirms that it is worthwhile pedagogically to pay more attention to vocabulary. It also indirectly raises an important question: who should be responsible for making the academic language norms explicit? It is not within the scope of this article to answer this question. Instead, this article looks at three pieces of guidance literature on academic writing in tertiary education to exemplify how academic language skills and particularly academic vocabulary are defined and conveyed. The purpose of this analysis is to come nearer to an understanding of the underlying assumptions that guide the teaching and learning of academic language skills, and to create support for the argument that is central to this article: we should put more focus on teaching academic vocabulary to L1, L2 and L3 students. 
[3] Focus on ACAdemic LANGuAge Skills in Guidance literature ON ACADEMIC WRITING

The three pieces of guidance literature analysed are:

(i) Vejledning i akademisk opgaveskrivning ved De Æstestiske Fag Kasernen, Aarhus Universitet (Guidance in writing academic papers at Aesthetic Subjects Kasernen, Aarhus University) (2013).

(ii) Den gode opgave - håndbog i opgaveskrivning på videregående uddannelser (Writing a good paper - a handbook for writing papers in tertiary education) (2012)

(iii) Opgaveskrivning på videregående uddannelser. En loereRbog (Writing papers in tertiary education. A teachers' guide) (1999)

The first two guides are aimed at students in tertiary education while the last one is aimed at teachers in tertiary education. I will refer to them as guide 1,2 , and 3, respectively, in the remainder of this article. Guide 1 is an example of a guide developed at the local institutional level. Guide 2 is one of the most popular handbooks on academic writing in Denmark, presently published in its fourth edition. All examples given from the three guides are translated by me. I will start my analysis of the three guides by briefly summarising their content, with a focus on how they define academic language.

Grounded in a specific discipline and in a local context, guide 1, Vejledning $i$ akademisk opgaveskrivning, offers advice on how to make sure academic student papers adhere to norms shared across the scientific community. A section is dedicated to explaining the significance of these norms for academic papers, and it is rightfully pointed out that science is both a cognitive and a communicative endeavour (G1, p. 7). It is explicitly stated that the guide does not include guidance on the linguistic norms of science or the writing process. It does, however, provide advice on general academic conventions in relation to citation, use of sources, and referencing. More concrete issues are also treated such as pagination, table of contents, chapter division, and typography. In its treatment of the scientific norms mentioned above, guide 1 also accounts for how the academic paper, just like the academic research article, can be seen as a macro-argument (cf. Shaw \& Vassileva 2009; Bloch 2010). Guide 1 can be said to focus on the global traits of an academic paper by providing the students with a number of useful guidelines in relation to the formalities, and hopefully by doing so, it contributes to raising awareness of academic conventions and norms among the students. Since guide 1 does not concern itself with the particulars 
of academic language, it does not provide the students with concrete tools for linguistic realisation of the content they wish to communicate. The guide fails to explain how the academic norms and conventions should be realised linguistically. This confirms the above-mentioned findings of how academic language norms are rarely explained and made explicit to most students.

Guide 2, Den gode opgave, is, as mentioned, a popular handbook in academic writing for students in tertiary education. This comprehensive book offers plenty of good advice on general academic conventions and how to adhere to them. In contrast to guide 1 , it takes language into consideration by devoting an entire chapter to academic language and by firmly stating that "the language expresses and co-creates the scientific content." (G2, p. 321). It lists two principles of academic language. The first principle states that the language of an academic paper must be scientific "and not necessarily varied, beautiful or appetizing" (G2, p. 321). The second principle states that it must be "clear and not necessarily difficult" (G2, p. 321). These normative principles on academic language relate to the assumptions and attitudes about academic language accounted for in the introduction of this article. Moreover, a central argument of guide 2 is that most academic language is learned within the disciplines, so therefore, students should consult their teachers for advice on academic language. Consequently, it is stressed that the guide only focuses on the general linguistic norms pertaining to the genre of the academic text (G2, p. 321). Thus, on the one hand, this guide acknowledges the importance of guiding the students in terms of how to realise the academic content linguistically, but on the other hand, it leaves the students to fend for themselves by referring them to the disciplines. Given that there is cause to believe that the particulars of academic language are seldom taught explicitly and are thus rarely salient to the students, it seems that while this guide does provide help to students in many areas pertaining to academic norms including language, perhaps unintentionally, it downplays the linguistic demands of academia. I will return to the content of guide 2 below.

Guide 3, Opgaveskrivning på videregående uddannelser, is written by the same authors as guide 2 and places the same emphasis on content and general academic skills. As mentioned, the book is aimed at teaching staff in tertiary education, and in line with guide 2, which advises students to consult their teachers for guidance on good academic language, guide 3 strongly encourages the teachers to guide their students as to what good academic language is. Guide 3 offers a number of valuable tools for the linguistic realisation of the academic functions described in the book. In fact, it offers more guidance on academic language than both guides 1 and 2, which is not surprising given the weight 
that both guide 2 and 3 attribute to the teachers with respect to conveying to the students "the norms of good academic language" (G2, p. 321).

The different elements of writing an academic paper constitute a process which here I term the academic workflow. I will use this term to account for how guides 2 and 3 further convey academic language and vocabulary in their accounts of the processes of academic writing. The academic workflow has at least three dimensions according to how the two guides structure their content. The first dimension is content-related, the focus being on the importance of constructing clear research questions, writing a good literature review, and having strategies for reading and note-taking. The second dimension pertains to general aspects of academic writing such as the writing process itself, but also general academic skills, i.e. knowledge of citation and referencing, genre conventions, argument structure, etc. Around 90 percent of the text in guide 2 covers these two dimensions of the academic workflow. The last dimension concerns the linguistic tools used in writing an academic paper. In guide 2, this linguistic aspect of the academic workflow is primarily treated in a separate chapter called "clear and academic language". This chapter discusses vocabulary and terminology, syntax, meta-communication and register. The linguistic dimension of academic writing is also treated in the chapter on argumentation, where a few concrete tools are given for how to structure and document an argument. In the chapter on how to use sources and make references, guide 2 receommends that "instead of using 'write', use one of these verbs to refer to others' work: 'analyse', 'describe', 'document', 'show'” (G2, p. 198). In total, the guide provides a list of 18 reporting verbs. Guide 2 also describes the do's and don'ts of academic speech acts (G2, p. 25), which can be likened to what was earlier in this article referred to as academic language functions.

The linguistic dimension of the academic workflow is even more explicit in guide 3, which continuously offers examples of vocabulary for e.g. signalling one's claim in an argument: "the claim is often signalled by 'therefore', 'consequently', (...) 'thus'.” (G3, p. 187). Guide 3 also supplies a useful list of connectors with different meta-communicative functions (G3, p. 269). Metacommunication is an important concept in both guides, and guide 2 also offers a few linguistic cues such as 'in this analysis' and 'as mentioned on page 7' for how to meta-communicate (G2, p. 333). Another example of linguistic tools being offered is the elaboration on how to use words to carry out academic functions in guide 2, p. 326. Three categories of words (cf. Stray Jørgensen 2004) are listed, each corresponding to important academic functions. The first category comprises what is termed 'investigation words', which are used to perform the academic functions of analysing, describing, interpreting, investigating, etc. 
Three explicit examples are given: 'choose', 'define', and 'conclude' together with the corresponding nouns: 'choice', 'definition', and 'conclusion'. The second category is 'knowledge words', which are words used to show how the writer makes use of the disciplinary theories and concepts for their investigation. Besides technical words, this category includes words used for metacommunication, and five examples are given. The last category is 'documentation words', which are used to document what is being investigated, and how it is being investigated. Examples of this category of words are 'i.e.', 'the argument for this is' and the 18 reference verbs mentioned above.

Thus, a number of concrete linguistic tools are given in these three guides (admittedly, guide 1 makes no claim to account for good academic language practice), but comparing the linguistic advice given to Danish students in guides 2 and 3 with the resources available in English, as accounted for above, it is clear that we need similar resources in Danish. Better resources would in turn enable the authors of these guides to give even more qualified advice on academic language.

\section{[4] CONCLUSION}

Each guide analysed here provides valuable and well-founded advice to students in tertiary education on how to deal with the challenging task of writing an academic paper. While guide 1 chooses to omit the language dimension of the academic workflow, the two other guides both emphasise the importance of mastering not only general academic skills, but also academic language skills when writing an academic paper. They even occasionally provide vocabulary examples of the academic functions they describe. However, after carefully analysing these guides, I am not sure they contribute to making the criteria of academic language any more explicit to the students. Perhaps guide 3's even more explicit focus on language is a way of making teachers in tertiary education more aware of the implicitness of what they themselves regard as good academic language. Yet, one could argue that the tools and resources available to teachers are limited (for examples on how the teaching of academic language can be integrated into discipline teaching, see http://cip.ku.dk/english/strategicinitiatives/languagestrategy/ ).

Moreover, as the research reviewed in this article shows, we have limited research-based knowledge of Danish academic vocabulary. There is a need for refining, elaborating and empirically strengthening concepts such as word categories and academic language functions via empirically based research into vocabulary in Danish academic language use. Such research should examine vocabulary types within academic language use and explore how to pedagogi- 
cally operationalise vocabulary types in the learning and teaching of academic language skills for L1, L2 and L3 students across different discipline-specific fields of study. The AcaDan corpus mentioned above can be an important resource for creating research-based knowledge of Danish academic vocabulary, which in turn can be employed in the development of pedagogical tools to be used in a more explicit teaching approach to academic language skills. Arguably, the more tangible the linguistic elements of academic competence are, the more visible and easier the norms of academic language should become for the students, which in turn may disprove citations like the one presented in the introduction of this article.

Academic language is not a superfluous nor unnecessarily complicated form of language use. Possessing adequate academic language skills, including a good grasp of technical as well as academic vocabulary, enables the academic, be it student or experienced researcher, to develop and convey abstract and technical ideas and facts with precision and nuance. Increasing the focus on the vocabulary aspect of academic language in the teaching of academic language skills may enable students to reach an academic language proficiency that meets the demanding norms of the various academic genres, and to understand the useful purposes that academic language serves.

\section{REFERENCES}

Ankersborg, Vibeke \& Karl-Heinz Pogner. 2016. (Almost) becoming an academic: About the embedded nature of Academic Literacy/ies. Paper presented at the conference LUNAS: Academic Language Use and Academic Literacies from a Multilingual Perspective in Nordic Educational Contexts, 9-11 May 2016, Copenhagen, Denmark.

Baptista, Jorge, Neuza Costa, Joaquim Guerra, Marcos Zampieri, Maria Cabral \& Numo Mamede. 2010. P-AWL: academic word list for Portuguese. Paper presented at the International Conference on Computational Processing of the Portuguese Language.

Biber, Douglas. 2006. University language: A corpus-based study of spoken and written registers (Vol. 23). John Benjamins Publishing Company.

Bloch, Joel. 2010. A concordance-based study of the use of reporting verbs as rhetorical devices in academic papers. Journal of Writing Research, 2(2), 219244.

Blom, Jonas Nygaard, Heidi Jønch-Clausen, Mariann Rathje, Jesper Tinggaard 
Svendsen, Anne Vibeke Lindø, Bjarne le Fevre Jakobsen, . . . Kenneth Reinecke Hansen. 2016. Academic Writing Proficiency of Danish University Students. Paper presented at the conference LUNAS: Academic Language Use and Academic Literacies from a Multilingual Perspective in Nordic Educational Contexts, 9-11 May 2016, Copenhagen, Denmark.

Carlund, Carina, Håkan Jansson, Sofie Johansson Kokkinakis, Julia Prentice \& Judy Ribeck, 2012. An academic word list for Swedish-a support for language learners in higher education. Paper presented at the Proceedings of the SLTC 2012 workshop on NLP for CALL, 25th October 2012, Lund, Sweden.

Cobb, Tom \& Marlise Horst. 2004. Is there room for an academic word list in French? Vocabulary in a second language 23, 15-38.

Coxhead, Averil. 2000. A new academic word list. TESOL quarterly, 34(2), 213-238.

Cummins, Jim. 1980. The Entry and Exit Fallacy in Bilingual Education. NABE: The Journal for the National Association for Bilingual Education, 4(3), 25-59.

Dang, Thi Ngoc Yen. 2017. Investigating Vocabulary in Academic Spoken English: Corpora, Teachers, and Learners. (Unpublished PhD Dissertation), Victoria University of Wellington, Wellington.

Gardner, Dee \& Mark Davies. 2014. A new academic vocabulary list. Applied Linguistics, 35(3), 305-327.

Gimbel, Jørgen. 1994. Undervisning af tyrkiske elever i Køge kommune (Vol. K3). Copenhagen: Danmarks Lærerhøjskole.

Gimbel, Jørgen. 1995. Bakker og udale. Sprogforum, tidskrift for sprog-og kulturpcedagogik, 3, 28-34.

Hansen, Thomas Holme, Marie Lund \& Henrik Kaare Nielsen. 2008. Vejledning $i$ akademisk opgaveskrivning ved Institut for Æstetiske Fag Kasernen, Aarhus Universitet. Aarhus Universitet.

Hauksdóttir, Audur. 2012. Dansk som fremmedsprog i en akademisk kontekst. Om isloendingenes behov for danskkundskaber under videreuddannelse $i$ Danmark (Anne Holmen Ed. Vol. 68). Copenhagen: Københavns Universitets Humanistiske Fakultet.

Henriksen, Birgit. 2014. Akademisk kompetence - en sproglig udfordring. Inaugural lecture 28 February 2014, University of Copenhagen. 
Holmen, Anne. 2016. Dansk som akademisk sprog for nordiske studerende. prog $i$ Norden.

Jakobsen, Anne Sofie. 2016. Investigating academic vocabulary in Danish academic writing. Poster presented at the conference LUNAS: Academic Language Use and Academic Literacies from a Multilingual Perspective in Nordic Educational Contexts, 9-11 May 2016, Copenhagen, Denmark..

Jansson, Håkan, Sofie Johansson Kokkinakis, Judy Ribeck \& Emma Sköldberg. 2012. A Swedish Academic Word List: Methods and Data. Paper presented at the Proceedings of the 15th EURALEX International Congress.

Hagen, Kristin, Janne Bondi Johannessen \& Arash Saidi. 2016. Constructing a Norwegian Academic Wordlist. Proceedings of the Tenth International Conference on Language Resources and Evaluation (LREC 2016), 1457 - 1462.

Knudsen, Sanne. 2009. Har du et problem? En undersøgelse af universitetsstuderendes forståelse, anvendelse og kommunikation af problemorienterede vidensproblemer. Dansk Universitetspaedagogisk Tidsskrift, 4(7), 49-57.

Kristiansen, Bente. 2010. Tekstproduktion og vidensproduktion. Dansk Universitetspoedagogisk Tidsskrift, 5 (9), 50-54.

Laursen, Helle Pia. 2006. Den sproglige dimension i naturfagsundervisningen. MONA, 2, 27-46.

Laursen, Katja Årosin. 2013. Det er sprogligt. Selv hvor du ikke loegger mæerke til det. En empirisk undersøgelse af sproglige og faglige vanskeligheder hos farmaceutstuderende med dansk som andetsprog på Københavns Universitet (Vol. C4). Copenhagen: Københavns Universitets Humanistiske Fakultet.

Leth-Andersen, Hanne \& Signe Skov. 2013. Akademisk sprog skal være alt andet end tågesnak. Politiken, 11 November 2013. http://politiken.dk/debat/debatindlaeg/art5483073/Akademisk-sprogskal-vC3\%A6re-alt-andet-end-t\%C3\%A5gesnak (retrieved 16 March 2017)

Lund, Karen. 2016. Kompleksiteten i akademisk sprogbrug belyst ved modelanalyser. Sprogforum, 63.

Lund, Karen \& Ellen Bertelsen. 2008a. Fra Studieprøven til de videregående uddannelser. En undersøgelse af de nødvendige og tilstrcekkelige kompetencer. København: Ministeriet for Flygtninge, Indvandrere og Integration. 
Lund, Karen \& Ellen Bertelsen. 2008b. At mestre et uddannelsesfagligt fremmed/andetsprog-en forudsætning på en videregående uddannelse. sprogforum, 17.

Møller, Pia Hildebrand. 2014. Sproglige og studiemcessige udfordringer hos studerende med dansk som andetsprog-pilotprojekt. Aarhus University.

Nagy, William \& Townsend, Dianna. 2012. Words as tools: Learning academic vocabulary as language acquisition. Reading Research Quarterly, 47 (1), 91-108.

Nation, Paul \& Hwang Kyongho. 1995. Where would general service vocabulary stop and special purposes vocabulary begin? System, 23 (1), 35-41.

Nation, Paul. 2013. Learning Vocabulary in Another Language (second edition). Cambridge: Cambridge University Press.

Odgaard, Stine Mosgaard. 2014. "Det er ikke et sprog, man bare kan samle op på gaden": en undersøgelse af behovet for kurser $i$ akademisk dansk for studerende med dansk som andetsprog på Institut for Tvœrkulturelle og regionale Studier på Københavns Universitet (Vol. C6). Copenhagen: Københavns Universitets Humanistiske Fakultet.

Paquot, Magali. 2010. Academic Vocabulary in Learner Writing: From Extraction to Analysis. Bloomsbury Publishing.

Paulsen, Egon Weber. 2009. Åbne sider At skelne det førfaglige ordforråd. sprogforum, 52 .

Ranney, Susan. 2012. Defining and Teaching Academic Language: Development in K-12 ESL. Language and Linguistic Compass 6/9 (2012): 560-574.

Rienecker, Lotte \& Peter Stray Jørgensen. 1999. Opgaveskrivning på videregående uddannelser-en loereRbog: Samfundslitteratur.

Rienecker, Lotte \& Peter Stray Jørgensen. 2012. Den gode opgave. 4. udgave: Samfundslitteratur.

Scheuer, Sebastian Reinert. (2016). Indrøm nu, at humaniora er sin egen værste fjende. Politiken, 15 February 2016, http://politiken.dk/debat/art5611453/Indr\%C3\%B8m-nu-at-humaniora-ersin-egen-v\%C3\%A6rste-fjende (retrieved 16 March 2017)

Shaw, Philip \& Irena Vassileva. 2009. Co-evolving academic rhetoric across culture; Britain, Bulgaria, Denmark, Germany in the 20th century. Journal of 
Pragmatics, 41(2), 290-305.

Simpson-Vlach, Rita \& Nick C. Ellis. 2010. An academic formulas list: New methods in phraseology research. Applied Linguistics, 31(4), 487-512.

Skov, Signe. 2013. Progression i de studerendes skrivekompetence. Spor-et tidsskrift for universitetspcedagogik(1), 1-8.

Skov, Signe. 2006a. Videnskabet: Du skriver ikke akademisk nok. Uniavisen, 25. maj 2006. https://uniavisen.dk/videnskabet-du-skriver-ikke-akademisknok/ (retrieved 16 March 2017)

Skov, Signe. 2006b. Hvordan bedømmer man det sproglige i universitetsopgaver? Dansk Universitetspæedagogisk Tidsskrift, 1(1), 18-25.

Sköldberg, Emma \& Sofie Johansson Kokkinakis. 2012. A och O om akademiska ord-Om framtagning av en svensk akademisk ordlista. Nordiske Studier $i$ Leksikografi(11).

Snow, Catherine E. 2010. Academic Language and the Challenge of Reading for Learning about Science. Science, 328(5977), 450-452.

Snow, Catherine E. \& Paola Uccelli. 2009. The challenge of academic language. In David R. Olson \& Nancy Torrance (Eds.). The Cambridge Handbook of Literacy. Cambridge: Cambridge University Press. 112-133.

Stray Jørgensen, Peter. 2004. Videnskabelig ord - sproglig rådgivning i videnskabelighed. In Henrik Jørgensen \& Peter Stray Jørgensen (Eds.). På godt dansk. Festskrift til Henrik Galberg Jacobsen $i$ anledning af hans 60 års fødselsdag 4. februar 2004. Wessel og Huitfeldt. 181-190.

Undervisningsministeriet (Ministry of Education). 2013. BEK nr. 776 af 26/06/2013 - Stx-bekendtgørelsen (Ministerial Order on Upper-Secondary School).

https://www.retsinformation.dk/Forms/R0710.aspx?id=152507\#Bil4 (retrieved 16 March 2017).

Udannelses- og forskningsministeriet (Ministry for Higher Education and Science). 2016. BEK nr. 1062 af30/06/2016 (Ministerial Order on University Examination). https://www.retsinformation.dk/forms/R0710.aspx?id=183445 (retrieved 16 March 2017). 
CONTACTS

Anne Sofie Jakobsen

University of Copenhagen, Denmark

asj@hum.ku.dk 